\title{
ANALISIS KETERSEDIAAN, KETERJANGKAUAN DAN PEMANFAATAN PANGAN DALAM MENDUKUNG TERCAPAINYA KETAHANAN PANGAN MASYARAKAT DI PROVINSI JAWA TENGAH
}

\author{
Analysis of Availability, Affordability and Utilization of Food in Supporting the \\ Achievement of Community Food Security in Central Java Province \\ Sri Pujiati ${ }^{1}$,Amelia Pertiwi ${ }^{1}$,Churun Cholina Silfia ${ }^{1}$,Dewa Maulana Ibrahim ${ }^{1}$, Siti \\ Hadiyati Nur Hafida ${ }^{1}$ \\ 1Program Studi Pendidikan Geografi, Fakultas Keguruan dan Ilmu Pendidikan, Universitas Muhammadiyah \\ Surakarta \\ *Kontakpenulis: sripujiati07030@gmail.com
}

\begin{abstract}
Food security becomes an aspect that needs to be considered, especially when the population and degradation of agricultural land are increasing. Many variables that affect the measurement of the food security index, and what is often used is the availability, affordability, and utilization of food. This study aims to determine the effect of food availability, affordability, and utilization variables on the food security index. This study uses a correlational design and multiple regression analysis techniques. All regions in Central Java Province were the objects of this study, there are 35 districts/cities. The results from this study showed that the three variables did not significantly influence the increase of the food security index. The result shows that the current food security index has been influenced by other variables. Therefore, the government needs to examine more closely the new variables that affect the food security index in order to develop a strategy to improve the food security index in Central Java Province, especially in the era of the industrial revolution 4.0.
\end{abstract}

Keywords: Food Security Index; Food Affordability; Food Availability; Food Utilization

Abstrak

Ketahanan pangan menjadi aspek yang perlu diperhatikan, khususnya saat penambahan jumlah penduduk dan degradasi lahan pertanian semakin meningkat. Banyak variabel yang mempengaruhi pengukuran indeks ketahanan pangan, dan yang seringkali digunakan adalah ketersediaan, keterjangkauan, dan pemanfaatan pangan. Penelitian ini bertujuan untuk mengetahui pengaruh variabel ketersediaan, keterjangkauan, dan pemanfaatan pangan terhadap indeks ketahanan pangan. Penelitian ini menggunakan desain korelasional dan teknik analisis regresi berganda. Seluruh wilayah di Provinsi Jawa Tengah menjadi obyek dalam penelitian ini, terdapat 35 kabupaten/kota. Hasil penelitian menunjukkan bahwa ketiga variabel tersebut tidak berpengaruh secara signifikan terhadap peningkatan indeks ketahanan pangan. Hal tersebut menunjukkan, indeks ketahanan pangan saat ini telah dipengaruhi oleh variabel lain. Oleh karena itu, pemerintah perlu mengkaji lebih dalam terhadap variabel apa saja yang mempengaruhi indeks ketahanan pangan agar dapat menyusun suatu strategi yang lebih sesuai untuk meningkatkan ketahanan pangan di Provinsi Jawa Tengah pada era revolusi industri 4.0 ini.

Kata Kunci: Indeks Ketahanan Pangan; Keterjangkauan Pangan; Ketersediaan Pangan; Pemanfaatan Pangan 
Sitasi: Pujiati S., A. Pertiwi, C.C. Silfia, D.M. Ibrahim, S.H.N. Hafida, 2020. Analisis ketersediaan, keterjangkauan dan pemanfaatan pangan dalam mendukung tercapainya ketahanan pangan masyarakat di provinsi jawa tengah , JSEP 16(2): $123-133$.

\section{Pendahuluan}

Indonesia merupakan Negara beriklim tropis yang terletak di garis khatulistiwa serta memiliki lahan terbuka hijau yang subur dan luas (Jaya, 2018; Wibowo, 2018). Hal ini dimanfaatkan oleh mayoritas penduduknya untuk bercocok tanam terutama dalam sektor pertanian (Kamaluddin et.al, 2012). Lahan pertanian mempunyai peran dan fungsi strategis sebagai sumberdaya pokok dalam usaha pertanian (Janti et al., 2016; Purwaningsih et al., 2015). Sektor pertanian merupakan sektor penting dalam suatu negara karena kebutuhan pokok dapat tercukupi dengan memanfaatkan hasil mentah dari sektor pertanian seperti padi yang nantinya akan diolah menjadi beras untuk dikonsumsi sebagai makanan pokok (Mulyo et al., 2015). Beras menjadi komoditas pangan utama yang sangat mempengaruhi ketahanan pangan di Indonesia sehingga ketersediaan stok beras yang dapat disediakan secara nasional menjadi salah satu faktor yang dapat mempengaruhi ketahanan pangan (Darwanto, 2005; Santosa \& Sudrajat, 2010).

Padi sebagai hasil sektor pertanian menjadi komoditas pangan tertinggi di Indonesia mengalahkan komoditas pangan lain, seperti: jagung, telur, ubi dan sayur. Tingginya produksi padi yang harus dihasilkan untuk memenuhi kebutuhan pangan berkaitan erat dengan tingginya konsumsi beras sebagai makanan pokok sebagian besar masyarakat. Pada tahun 2013, rata-rata konsumsi padi nasional menunjukkan angka sebesar 97,36 kg/kapita (BPS Provinsi Jawa Tengah, 2013). Angka konsumsi beras yang tinggi tidak berbanding lurus dengan angka produksi padi. Hal ini pada akhirnya dapat berpengaruh terhadap ketahanan pangan, terutama ketahanan pangan pada wilayah penghasil komoditas tersebut. Masyarakat harus memperhatikan ketersediaan padi dan juga akses pangan yang ada di suatu wilayah agar wilayah tersebut mampu disebut sebagai wilayah yang tahan pangan. Hal tersebut sesuai dengan pernyataan Ali et al. (2017) dan Fauzi et al., (2019) yang menyatakan bahwa, setiap orang harus memiliki aksesibilitas fisik dan ekonomi terhadap pangan yang cukup untuk memenuhi kebutuhan pangan agar hidup sehat dan produktif.

Ketahanan pangan merupakan isu multidimensi yang sangat kompleks (Suryana, 2014). Permasalahan ketahanan pangan tidak hanya terjadi di Indonesia, seluruh Negara di dunia juga mengalami permasalahan ketahanan pangan oleh karena itu, Food and Agriculture Organization (FAO) senantiasa memberikan informasi terkini kondisi pangan di berbagai negara. FAO mendukung pengembangan kapasitas pemerintah dan masyarakat dalam menghadapi tantangan ketahanan pangan dan gizi (Berek, 2018). Hal tersebut sesuai dengan Undang-undang Nomor 7 (1996) yang menyatakan bahwa, suatu wilayah harus mampu menyediakan pangan yang aman, merata, dan terjangkau bagi semua warganya agar tercapai ketahanan pangan di wilayah tersebut. 
Susanti (2017) juga menyatakan bahwa ketahanan pangan merupakan suatu tingkat kebutuhan pangan dan gizi setiap individu maupun kelompok masyarakat dalam pemenuhan derajat kesehatan dan kesejahteraannya. Oleh karena itu, ketahanan pangan merupakan kondisi pemenuhan pangan yang aman dan bergizi pada setiap masyarakat untuk mendukung tercapainya kesehatan dan kesejahteraan masyarakat disuatu wilayah.

Ketahanan pangan akan berkaitan dengan kemampuan pemenuhan pangan setiap individu dalam rumahtangga. Semakin banyak anggota rumahtangga maka kebutuhan pangan akan semakin meningkat. Oleh karena itu, rumahtangga merupakan salah satu obyek terpenting dalam pemenuhan kebutuhan pangan nasional ataupun komunitas dan individu (Purwaningsih, 2008). Banyak masyarakat yang masih belum memahami pentingnya memenuhi pangan secara mandiri sehingga, membangun kapasitas dan kemandirian masyarakat merupakan tantangan utama dalam mendukung ketahanan pangan di tingkat rumahtangga (Ediwiyati et al., 2015). Ketahanan pangan suatu wilayah dapat dikategorikan berhasil apabila peningkatan produksi dan distribusi pangan berjalan lancar serta konsumsi pangan aman dan berkecukupan untuk memenuhi gizi masyarakatnya (Rahmawati, 2012). Jawa Tengah merupakan salah satu Provinsi di Indonesia yang menjadi penyangga pangan nasional dan sebagai lumbung padi regional maupun nasional (Windiani, 2012). Banyaknya produksi padi di Provinsi Jawa Tengah sangat diharapkan mampu mendukung pemenuhan pangan di Provinsi Jawa Tengah itu sendiri.

Pemenuhan pangan akan berkaitan dengan kesesuaian antara produksi sektor pertanian dengan kebutuhan pangan masyarakatnya. Produksi komoditas pangan di suatu wilayah bergantung pada seberapa luas panen pada tahun yang bersangkutan. Semakin masifnya permasalahan degradasi lahan pertanian menjadi salah satu penyebab produksi komoditas pangan semakin tahun semakin mengalami penurunan. Menurut Putri (2015), pada Tahun 2014 terdapat $6.725 .625 \mathrm{~m}^{2}$ lahan yang mengalami alih fungsi dan dimungkinkan pada Tahun 2023 Provinsi Jawa Tengah akan mengalami alih fungsi lahan mencapai 13.434.610 $\mathrm{m}^{2}$. Perhitungan tersebut dilakukan melalui analisis trend alih fungsi lahan di Provinsi Jawa Tengah. Perhitungan tersebut menunjukkan bahwa produksi komoditas pangan dapat mengalami penurunan yang sangat drastis akibat semakin meningkatnya alih fungsi lahan yang terjadi. Pemenuhan pangan juga bergantung pada jumlah penduduk yang ada di suatu wilayah.

Angka kebutuhan pokok untuk memenuhi kebutuhan hidup di wilayah Provinsi Jawa Tengah semakin meningkat. Hal tersebut disebabkan karena semakin meningkatnya jumlah penduduk di Provinsi Jawa Tengah. Jumlah penduduk Provinsi Jawa Tengah pada tahun 2010 tercatat sebanyak 32.443.886 jiwa, sedangkan pada tahun 2019 jumlah penduduk sebanyak 34.718.204 jiwa, dengan laju pertumbuhan penduduk per tahun dari tahun 2000-2010 yaitu 0,37\% dan mengalami kenaikan menjadi 0,78\% per tahun dari tahun 2010-2019(2020 BPS Provinsi Jawa Tengah, 2020). Peningkatan jumlah penduduk dapat mempengaruhi aspek ketersediaan pangan. Ketersediaan pangan berhubungan dengan luas lahan sawah, luas lahan panen, luas tanam dan produktivitas padi (Santosa \& Sudrajat, 2010). Ketersediaan komoditas pangan dengan kebutuhan 
konsumsi beras harus seimbang. Jumlah penduduk pada suatu wilayah juga sangat berpengaruh terhadap ketersediaan pangan agar dapat tercapai keseimbangan. Apabila angka ketersediaan beras lebih rendah dari kebutuhan konsumsi beras, maka wilayah tersebut dapat dikatakan defisit beras dan mempengaruhi kesejahteraan masyarakat pada suatu wilayah.

Langkah tepat pemerintah untuk menghadapi kondisi seperti ini adalah dengan melakukan analisis mengenai ketahanan pangan untuk mengatasi kerawanan pangan. Upaya pencegahan dan upaya untuk mengatasinya harus dilaksanakan secara cepat dan dikelola dengan baik agar terhindar dari kerawanan pangan. Kerawanan pangan dapat diatasi dengan melakukan peningkatan ketahanan pangan (Fauzi et al., 2019). Upaya yang dapat dilakukan oleh masyarakat dalam menanggulangi kerawanan pangan antara lain melalui kegiatan Pendidikan Kesejahteraan Keluarga (PKK), pemberdayaan posyandu, kepedulian sosial, dasawisma, dan aktifitas sosial keagamaan (Eriningsih \& Rachman, 2008).

Ketahanan pangan memiliki peranan yang sangat penting dalam pemenuhan kebutuhan pangan tiap individu. Terdapat suatu indeks penilaian yang dapat mengetahui tingkat ketahanan pangan pada suatu wilayah yang disebut dengan Indeks Ketahanan Pangan (IKP). Indeks ini mencakup berbagai faktor pendukung yang mempengaruhi ketahanan pangan, antara lain ketersediaan, keterjangkauan, dan yang terakhir adalah pemanfaatan pangan (Badan Ketahanan Pangan, 2018). Terpenuhinya ketiga aspek tersebut diharapkan dapat mengurangi permasalahan pangan di suatu wilayah. Namun, saat ini kondisi ketahanan pangan di setiap wilayah menunjukkan perbedaan dengan kondisi ketahanan pangan di tingkat nasional. Ketersediaan pangan di level nasional belum tentu menjamin adanya ketersediaan pangan di level provinsi/kabupaten. Oleh karena itu, penguatan ketahanan pangan suatu daerah harus dimulai agar dapat mendukung tercapainya ketahanan pangan tingkat nasional (Ariani, 2005). Banyaknya kebijakan impor bahan pangan juga pada akhirnya mempengaruhi ketersediaan pangan di suatu wilayah, sehingga pemberdayaan ketahanan pangan masyarakat dan pengembangan sistem usaha agrobisnis merupakan strategi yang dapat digunakan untuk mencapai keberhasilan pembangunan ketahanan pangan (Hanafie, 2010). Penelitian ini bertujuan untuk menganalisis hubungan antara variabel ketersediaan, keterjangkauan dan pemanfaatan pangan dalam mendukung tercapainya ketahanan pangan di Provinsi Jawa Tengah.

\section{Metode Penelitian}

Penelitian ini menggunakan desain korelasional. Desain korelasional memiliki tujuan untuk menghubungkan dua variabel atau lebih (Agustina \& Priambodo, 2017). Desain korelasional dalam penelitian ini bertujuan untuk menganalisis keterkaitan variabel ketersediaan, keterjangkauan, dan pemanfaatan pangan terhadap indeks ketahanan pangan. Penelitian ini dilakukan disemua kabupaten/kota yang berada di Provinsi Jawa Tengah yakni Kabupaten Cilacap, Banyumas, Purbalingga, Kebumen, Purworejo, Wonosobo, Magelang, Boyolali, Klaten, Sukoharjo, Wonogiri, Karanganyar, Sragen, Grobogan, Blora, Rembang, Pati, Kudus, Jepara, Demak, Semarang, Temanggung, 
Kendal, Batang, Pekalongan, Pemalang, Tegal, Brebes, Kota Magelang, Kota Surakarta, Kota Salatiga, Kota Semarang, Kota Pekalongan, dan Kota Tegal.

Penelitian ini dilakukan dengan metode dokumentasi dari laporan Kementerian Pertanian dan Badan Pusat Statistik (BPS) Provinsi Jawa Tengah, khususnya yang terkait dengan data analisis sosial ekonomi tahun 2013, survey pertanian tahun 2013, indeks ketahanan pangan Indonesia tahun 2018, dan laporan tahunan badan ketahanan pangan tahun 2018. Penelitian ini berkaitan dengan faktor-faktor yang mempengaruhi ketahanan pangan di Provinsi Jawa Tengah. Analisis yang digunakan untuk mengukur ketahanan pangan masyarakat dilakukan dengan menggunakan pendekatan deskriptif kuantitatif. Teknik analisis data berupa analisis regresi linier berganda. Analisis regresi linier berganda adalah analisis yang memiliki jumlah variabel independent (bebas) lebih dari satu (Pratomo \& Astuti, 2016). Dalam penelitian ini analisis regresi linier berganda bertujuan untuk mengidentifikasi pengaruh variabel ketersediaan, keterjangkauan dan pemanfaatan pangan terhadap peningkatan indeks ketahanan pangan di Provinsi Jawa Tengah.

\section{Hasil dan Pembahasan}

\section{Hasil}

Tiga variabel yang selama ini memiliki pengaruh besar dalam mencapai ketahanan pangan adalah ketersediaan, keterjangkauan, dan pemanfaatan pangan. Masing-masing variabel tersebut memiliki nilai yang berbeda-beda di Provinsi Jawa Tengah. Tabel 1 menunjukkan nilai dari masing-masing variabel yang ada di Provinsi Jawa Tengah.

Tabel 1. Nilai ketahanan, ketersediaan, keterjangkauan, dan pemanfaatan pangan di Provinsi Jawa Tengah

\begin{tabular}{|l|c|c|c|c|}
\hline Kabupaten & $\begin{array}{c}\text { Indeks } \\
\text { Ketahanan } \\
\text { Pangan }\end{array}$ & $\begin{array}{c}\text { Nilai } \\
\text { Ketersediaan } \\
\text { Pangan }\end{array}$ & $\begin{array}{c}\text { Nilai } \\
\text { Keterjangkauan } \\
\text { Pangan }\end{array}$ & $\begin{array}{c}\text { Nilai } \\
\text { Pemanfaatan } \\
\text { Pangan }\end{array}$ \\
\hline Cilacap & 79.19 & 93.59 & 93.24 & 71.29 \\
\hline Banyumas & 73.99 & 90.14 & 89.44 & 69.68 \\
\hline Purbalingga & 74.00 & 89.95 & 85.61 & 71.48 \\
\hline Banjarnegara & 72.35 & 92.94 & 88.91 & 67.87 \\
\hline Kebumen & 73.32 & 93.15 & 92.73 & 68.02 \\
\hline Purworejo & 78.63 & 98.07 & 97.64 & 69.71 \\
\hline Wonosobo & 75.87 & 92.19 & 89.57 & 74.68 \\
\hline Magelang & 76.32 & 91.6 & 88.27 & 69.64 \\
\hline Boyolali & 80.36 & 94.26 & 89.62 & 71.05 \\
\hline Klaten & 78.69 & 94.49 & 91.8 & 70.35 \\
\hline Sukoharjo & 85.21 & 93.72 & 94.17 & 75.77 \\
\hline Wonogiri & 81.83 & 92.5 & 92.23 & 71.51 \\
\hline Karanganyar & 82.40 & 96.1 & 95.00 & 73.97 \\
\hline Sragen & 82.22 & 96.1 & 97.08 & 75.55 \\
\hline Grobogan & 81.19 & 92.74 & 92.09 & 74.02 \\
\hline
\end{tabular}




\begin{tabular}{|l|c|c|c|c|}
\hline Blora & 81.30 & 92.47 & 91.41 & 75.45 \\
\hline Rembang & 77.71 & 89.6 & 88.58 & 79.41 \\
\hline Pati & 84.04 & 93.19 & 93.58 & 80.15 \\
\hline Kudus & 82.31 & 94.77 & 94.14 & 75.97 \\
\hline Jepara & 80.95 & 93.67 & 88.59 & 71.86 \\
\hline Demak & 84.11 & 92.56 & 91.61 & 85.21 \\
\hline Semarang & 82.66 & 93.88 & 89.32 & 70.23 \\
\hline Temanggung & 79.27 & 93.21 & 88.41 & 69.41 \\
\hline Kendal & 80.84 & 91.66 & 92.21 & 76.97 \\
\hline Batang & 77.10 & 93.36 & 90.26 & 72.38 \\
\hline Pekalongan & 71.17 & 95.27 & 90.15 & 70.48 \\
\hline Pemalang & 74.96 & 92.86 & 92.57 & 72.37 \\
\hline Tegal & 74.70 & 95.82 & 95.29 & 74.68 \\
\hline Brebes & 72.55 & 89.8 & 86.6 & 79.30 \\
\hline Kota Magelang & 78.43 & 98.9 & 98.51 & 88.08 \\
\hline Kota Surakarta & 77.65 & 100.00 & 100.00 & 88.66 \\
\hline Kota Salatiga & 81.09 & 95.37 & 85.13 & 80.01 \\
\hline Kota Semarang & 85.93 & 95.52 & 90.07 & 78.33 \\
\hline $\begin{array}{l}\text { Kota } \\
\text { Pekalongan }\end{array}$ & 62.42 & 97.28 & 97.83 & 81.64 \\
\hline Kota Tegal & 67.18 & 94.41 & 90.15 & 97.57 \\
\hline
\end{tabular}

Sumber:BPS Provinsi Jawa Tengah, 2013 dan Badan Ketahanan Pangan, 2018

Berdasarkan Tabel 1, Kota Semarang memiliki indeks ketahanan pangan tertinggi dengan nilai sebesar 85,93. Urutan tertinggi kedua yaitu Kabupaten Sukoharjo dengan indeks ketahanan pangan sebesar 85,21. Kota Pekalongan merupakan wilayah di Provinsi Jawa Tengah dengan indeks ketahanan pangan terendah, yaitu 62,42. Rata-rata indeks ketahanan pangan Provinsi Jawa Tengah yaitu 0,78. Menurut Fauzi, Kataman \& Pujianto (2019), jika suatu wilayah memiliki nilai indeks ketahanan pangan $>0,75-1$ maka termasuk dalam kategori aman. Hal tersebut menunjukkan bahwa wilayah yang ada di Provinsi Jawa Tengah termasuk dalam kategori aman pangan karena memiliki rata-rata indeks ketahanan pangan 0,78 .

Ketersediaan pangan di Provinsi Jawa Tengah dapat dikatakan baik. Hal tersebut dikarenakan rata-rata nilai ketersediaan pangan di seluruh kabupaten/kota di Provinsi Jawa Tengah mencapai angka 90, bahkan Kota Surakarta menjadi wilayah yang memiliki nilai ketersediaan pangan tertinggi dengan nilai 100. Hanya beberapa wilayah yang memiliki nilai ketersediaan pangan pada angka 80, diantaranya Kabupaten Purbalingga dengan nilai sebesar 89,95, Kabupaten Rembang 89,6, dan Kabupaten Brebes sebesar 89,8. Ketiga kabupaten ini memiliki nilai ketersediaan pangan yang rendah dikarenakan kondisi geografis wilayahnya. Kabupaten Purbalingga merupakan kabupaten yang berada di lereng Gunung Slamet, Kabupaten Brebes merupakan kabupaten yang terletak disekitar kawasan pantai, sedangkan Kabupaten Rembang bagian selatannya merupakan bagian dari kawasan Pegunungan Kapur Utara. Kondisi tersebut pada akhirnya menyebabkan ketiga wilayah memiliki jumlah ketersediaan pangan yang lebih sedikit dibandingkan dengan wilayah lain yang ada di Provinsi Jawa Tengah. 
Keterjangkauan pangan di Provinsi Jawa Tengah sesuai dengan Tabel 1 menunjukkan bahwa Kota Salatiga merupakan wilayah yang memiliki nilai keterjangkauan pangan terendah, yaitu 85,13. Kota Surakarta menjadi wilayah yang memiliki nilai keterjangkauan pangan tertinggi yaitu 100. Rata-rata seluruh wilayah di Provinsi Jawa Tengah memiliki nilai keterjangkauan pangan antara 8090.

Nilai pemanfaatan pangan tertinggi berada di Kota Tegal dengan nilai 97,57. Banyak kabupaten/kota di Provinsi Jawa Tengah yang mempunyai nilai pemanfaatan pangan sebesar 80, bahkan ada beberapa kabupaten/kota yang memiliki nilai 60. Nilai pemanfaatan pangan terendah berada di Kabupaten Temanggung, yaitu sebesar 69,4 (Tabel 1).

Saat ini perkembangan sektor pertanian sangat dinamis. Banyak wilayah yang tiba-tiba mengalami kondisi rawan pangan dan ada beberapa wilayah yang dapat meningkatkan kondisi ketahanan pangannya. Untuk mengetahui hubungan antara ketersediaan, keterjangkauan, dan pemanfaatan pangan terhadap indeks ketahanan pangan di Provinsi Jawa Tengah maka penelitian ini menggunakan analisis regresi linier berganda. Hasil analisis regresi linier berganda bermanfaat untuk mengetahui keterkaitan antara setiap variabel independen terhadap variabel dependen (ketahanan pangan) (Tabel 2).

Tabel 2. Pengaruh Indeks Ketahanan Pangan dan Ketersediaan, Keterjangkauan dan Pemanfaatan Pangan

\begin{tabular}{|l|r|r|r|r|r|}
\hline Model & \multicolumn{1}{|c|}{$\begin{array}{c}\text { Sum of } \\
\text { Squares }\end{array}$} & \multicolumn{1}{c|}{ df } & $\begin{array}{c}\text { Mean } \\
\text { Square }\end{array}$ & F & Sig. \\
\hline Regression & 18.201 & 3 & 6.067 & .216 & $.884^{\mathrm{b}}$ \\
1 & 870.115 & 31 & 28.068 & & \\
\multicolumn{1}{|l}{ Residual } & 888.316 & 34 & & & \\
\hline
\end{tabular}

a. Dependent Variable: Indeks Ketahanan Pangan (Y)

b. Predictors: (Constant), Pemanfaatan Pangan (X3),

Keterjangkauan Pangan (X2), Ketersediaan Pangan (X1)

Tabel 2 menunjukkan dasar pengambilan keputusan uji f simultan (regresi linier berganda) berdasarkan nilai signifikansi, nilai hitung, dan nilai tabel. Menurut Fajaryani (2015), jika nilai signifikansi <0,05 maka artinya secara simultan variabel independent $(\mathrm{X})$ berpengaruh terhadap variabel dependent $(\mathrm{Y})$. Nilai signifikansi pada tabel 2 yaitu sebesar 0,884 >0,05, maka dapat disimpulkan bahwa ketersediaan pangan (X1), keterjangkauan pangan (X2), dan pemanfaatan pangan (X3) secara simultan tidak berpengaruh terhadap indeks ketahanan pangan (Y). Fajaryani (2015) juga menyatakan jika nilai $f_{\text {hitung }}>f_{\text {tabel }}$ maka artinya variabel indepedent $(\mathrm{X})$ berpengaruh terhadap variabel dependent $(\mathrm{Y}) . F_{\text {hitung }}$ pada tabel 2 adalah sebesar 0,216, sedangkan $\mathrm{f}$ tabelnya adalah:

$$
\begin{aligned}
f_{\text {tabel }} & =\mathrm{k} ; \mathrm{n}-\mathrm{k} \\
& =3 ; 35-3 \\
& =3 ; 32 \\
& =2,92
\end{aligned}
$$

Artinya $f_{\text {hitung }}(0,216) \quad<f_{\text {tabel }}(2,92)$ sehingga dapat disimpulkan bahwa ketersediaan pangan (X1), keterjangkauan pangan (X2), dan pemanfaatan pangan (X3) secara simultan tidak berpengaruh terhadap indeks ketahanan pangan ( $\mathrm{Y}$ ). 
Tabel 3 menunjukkan dasar pengambilan keputusan uji t parsial berdasarkan nilai signifikansi, nilai hitung dan nilai tabel juga dari tabel koefisien.

Tabel 3. Koefisiensi Indeks Ketahanan Pangan dan Ketersediaan, Keterjangkauan dan Pemanfaatan Pangan

\begin{tabular}{|c|c|c|c|c|c|c|c|}
\hline \multirow[t]{2}{*}{ Model } & \multicolumn{2}{|c|}{$\begin{array}{c}\text { Unstandardized } \\
\text { Coefficients }\end{array}$} & $\begin{array}{l}\text { Standardized } \\
\text { Coefficients }\end{array}$ & \multirow[t]{2}{*}{$\mathrm{t}$} & \multirow[t]{2}{*}{ Sig. } & \multicolumn{2}{|c|}{ Collinearity Statistics } \\
\hline & B & Std. Error & Beta & & & Tolerance & VIF \\
\hline (Constant) & 74.150 & 35.264 & & 2.103 & .044 & & \\
\hline Ketersediaan Pangan (X1) & .041 & .563 & .020 & .074 & .942 & .439 & 2.276 \\
\hline${ }^{1}$ Keterjangkauan Pangan (X2) & .093 & .372 & .066 & .250 & .805 & .454 & 2.205 \\
\hline Pemanfaatan Pangan (X3) & -.113 & 146 & -.145 & -.770 & 447 & .890 & 1.124 \\
\hline
\end{tabular}

a. Dependent Variable: Indeks Ketahanan Pangan (Y)

Menurut Fajaryani (2011) jika nilai sig < 0,05 maka artinya secara parsial variabel independent $(\mathrm{X})$ berpengaruh terhadap variabel dependent $(\mathrm{Y})$. Pada tabel 3 diatas terlihat jika semua variabel mempunyai nilai sig $>0,05$ sehingga dapat disimpulkan bahwa secara parsial semua variabel dependent (X1, X2, dan X3) tidak berpengaruh terhadap Indeks Ketahanan Pangan (Y). Fajaryani (2015) juga menayatakan, jika nilai $t_{\text {hitung }}>t_{\text {tabel }}$ maka artinya variabel independent $(X)$ secara parsial berpengaruh terhadap variabel dependent $(\mathrm{Y})$. Rumus mencari $t_{\text {tabel }}$ adalah:

$$
\begin{aligned}
t_{\text {tabel }} & =\mathrm{a} / 2 ; \mathrm{n}-\mathrm{k}-1 \\
& =0,05 ; 35-3-1 \\
& =0,025 ; 31 \\
& =2,040
\end{aligned}
$$

Semua variabel independent (X1,X2, dan $\mathrm{X} 3)$ pada tabel 3 menunjukan bahwa nilai $t_{\text {hitung }}<t_{\text {tabel }}$ sehingga secara parsial ketersediaan pangan (X1), keterjangkauan pangan $(\mathrm{X} 2)$, dan pemanfaatan pangan $(\mathrm{X} 3)$ tidak berpengaruh terhadap indeks ketahanan pangan $(\mathrm{Y})$.

\section{Pembahasan}

Berdasarkan hasil analisis menggunakan analisis regresi linier berganda menunjukkan bahwa variabel ketersediaan, keterjangkauan, dan pemanfaatan pangan tidak berpengaruh terhadap indeks ketahanan pangan di Provinsi Jawa Tengah. Hal tersebut menunjukkan, indeks ketahanan pangan saat ini telah dipengaruhi oleh variabel lain, seperti luas lahan pertanian dan penduduk miskin (Destianto \& Pigawati, 2014; Suriadi 2010). Seiring perkembangan ekonomi suatu wilayah, luas lahan pertanian semakin menurun dikarenakan perubahan fungsi lahan sawah ke penggunaan lain. Terjadinya perubahan alih fungsi lahan pertanian menjadi ancaman yang serius terhadap keberlanjutan ketahanan pangan suatu wilayah. Perubahan lahan pertanian disebabkan oleh peningkatan jumlah penduduk yang berpengaruh terhadap penambahan permintaan lahan permukiman (Destianto \& Pigawati, 2014). Hal tersebut secara tidak langsung akan mempengaruhi keberadaan penduduk miskin yang semakin sulit mendapatkan tempat tinggal. Kondisi kemiskinan penduduk akan mempengaruhi keterjangkauan pangan dan akan berpengaruh terhadap ketahanan pangan (Suriadi, 2010).Pemerintah perlu mengkaji lebih dalam terhadap variabel yang mempengaruhi indeks ketahanan pangan agar dapat menyusun suatu strategi yang lebih sesuai untuk meningkatkan ketahanan pangan di Provinsi Jawa Tengah. 
Menurut Hanafie (2010), terdapat dua cara yang dapat digunakan untuk meningkatkan ketahanan pangan, yaitu mendorong peningkatan daya beli masyarakat miskin dengan cara menaikan tingkat produksi pangan secara simultan dan pendistribusian kembali supply pangan untuk wilayah kurang pangan menggunakan sistem yang bisa membantu meningkatkan daya beli masyarakat, khususnya masyarakat miskin dan menaikkan insentif untuk meningkatkan produksi pangan dalam jangka panjang. Hal tersebut sesuai dengan kebijakan Kementerian Pertanian (2015) yang menyatakan bahwa terdapat lima strategi utama dalam mencapai peningkatan ketahanan pangan, antara lain: (1) memprioritaskan pembangunan ekonomi dibidang pertanian dan pedesaan untuk meningkatkan produksi pangan domestik, menyediakan lapangan pekerjaan, dan meningkatkan penghasilan masyarakat, (2) penyediaan pangan untuk masyarakat yang tergolong miskin dan masyarakat yang terdampak bencana alam maupun sosial, (3) pemanfaatan sumber daya alam lokal untuk pemenuhan pangan yang beragam, bergizi, seimbang dan aman (B2SA), (4) melakukan sosialisasi dan edukasi untuk memanfaatkan pangan yang beragam, bergizi, seimbang dan aman (B2SA) dari sumber daya alam lokal kepada masyarakat, (5) penanggulangan keamanan pangan segar.

\section{Kesimpulan}

Berdasarkan analisis data yang dilakukan oleh peneliti, dapat disimpulkan bahwa tidak terdapat hubungan antara ketersediaan pangan, keterjangkauan pangan, dan pemanfaatan pangan dengan indeks ketahanan pangan masyarakat di Provinsi Jawa Tengah. Terdapat aspek lain yang dapat mempengaruhi indeks ketahanan pangan suatu wilayah, misalnya luas lahan pertanian dan penduduk miskin (Destiano \& Pigawati, 2014; Suriadi, 2010). Aspek-aspek lain yang kemungkinan berpengaruh terhadap indeks ketahanan pangan harus lebih diperhatikan oleh pemerintah agar dapat mengetahui upaya apa yang harus dilakukan untuk meningkatkan ketahanan pangan suatu wilayah. Pemerintah provinsi, kabupaten, maupun daerah perlu melaksanakan kebijakan yang berkaitan dengan ketahanan pangan. Program atau kebijakan yang dikembangkan untuk mendorong dan meningkatkan ketahanan pangan harus dijadikan prioritas pembangunan daerah. Akan tetapi hal tersebut tidak hanya menjadi tanggung jawab pemerintah, namun juga diharapkan peran, partisipasi dan tanggung jawab dari masyarakat. Pemerintah lebih bersifat menjadi fasilitator, sedangkan masyarakat dapat berperan sesuai dengan kapasitas dan potensi yang dimiliki oleh masing-masing kelompok/individu (Ariani, 2005; Eriningsih \& Rachman, 2008).

\section{Daftar Pustaka}

Agustina, A. T., \& Priambodo, A. (2017). Hubungan Antara Tingkat Konsentrasi Terhadap Hasil Ketepatan Shooting Olahraga Petanque Pada Peserta Unesa Petanque Club. Pendidikan Olahraga Dan Kesehatan, 5(3), 391-395.

Ali, M.S.S, A. Majika, D. Salman, 2017. Food Cosumption and Production of Tempe Lake, South Sulawesi, Indonesia. Journal of Asian Rural Studies, Vol.1, Issue 1: 4352. 
Ariani, M. (2005). Penguatan Ketahanan Pangan Daerah Untuk Mendukung Ketahanan Pangan Nasional. 23-37.

Badan Ketahanan Pangan, 2018. (2018). Indeks ketahanan pangan.

Berek, R. B. (2018). Peran Food And Agriculture Organization (FAO) Dalam Meningkatkan Ketahanan Pangan di Provinsi Nusa Tenggara Timur Melalui Program Pertanian Konservasi. Global Political Studies, 2(2), 161-176.

BPS Provinsi Jawa Tengah, 2013. (2013). Analisis Sosial Ekonomi Petani di Jawa Tengah.

BPS Provinsi Jawa Tengah, 2020. (2020). Dalam angka 2020.

Darwanto. (2005). Ketahanan Pangan Berbasis Produksi dan Kesejahteraan Petani. Ilmu Pertanian, 12(2), 152-164.

Destianto, R., \& Pigawati, B. (2014). Analisis Keterkaitan Perubahan Lahan Pertanian Terhadap Ketahanan Pangan Kabupaten Magelang Berbasis Model Spatio Temporal SIG. Geoplaning, 1(1), 21-32.

Ediwiyati, R., Koestiono, D., \& Setiawan, B. (2015). Analisis Ketahanan Pangan Rumah Tangga (Studi Kasus Pada Pelaksanaan Program Desa Mandiri Pangan di Desa Oro Bulu Kecamatan Rembang Kabupaten Pasuruan). XV(2).

Eriningsih, E., \& Rachman, H. P. S. (2008). Strategi Peningkatan Ketahanan Pangan Rumah Tangga Rawan Pangan. 6(3), 239-255.

Fajaryani, A. (2015). Analisis Faktor-faktor yang Mempengaruhi Integritas Laporan Keuangan (Studi Empiris pada Perusahaan Pertambangan yang Terdaftar di Bursa Efek Indonesia Periode 2008-2013). Nominal, IV(1), 67-82.

Fauzi, M., Kastaman, R., \& Pujianto, T. (2019). Pemetaan Ketahanan Pangan Pada Badan Koordinasi Wilayah I Jawa Barat. Industri Pertanian, 1(1), 1-10.

Hanafie, R. (2010). Penyediaan Pangan yang Aman dan Berkelanjutan Guna Mendukung Tercapainya Ketahanan Pangan. 4(3).

Janti, G. I., Martono, E., \& Subejo. (2016). Perlindungan Lahan Pertanian Pangan Berkelanjutan Guna Memperkokoh Ketahanan Pangan Wilayah (Studi di Kabupaten Bantul, Daerah Istimewa Yogyakarta). Ketahanan Naional, 22(1), 1-21.

Jaya, P. H. I. (2018). Nasib Petani Dan Ketahanan Pangan Wilayah ( Studi Tentang Kebijakan Pemerintah Dan Respons Masyarakat Desa Mulyodadi , Bantul Ketika Harga Komoditas Pertanian Naik ). Ketahanan Naional, 24(1), 77-79.

Kamaluddin, A., A.Ala, M.S.S. Ali, D. Salman, 2012. The Adaptation of Rice Paddy Farmers Towards Climate Change. American-Eurasian of Agricultural $\mathcal{E}$ Environmental Sciences. Vol.12, Issue 7: 967-972.

Mulyo, J. H., Sugiyarto, \& Widada, A. W. (2015). Ketahanan dan Kemandirian Pangan Rumah Tangga Tani Daerah Marginal di Kabupaten Bojonegoro. Agro Ekonomi, 26(2), 121-128.

Pertanian, K. (2015). Rencana Strategis Badan Ketahanan Pangan Tahun 2015-2019.

Pratomo, D. S., \& Astuti, E. Z. (2016). Regresi linier sederhana.

Purwaningsih, Y. (2008). Ketahanan Pangan: Situasi, Permasalahan, Kebijakan, dan 
Pemberdayaan Masyarakat. Ekonomi Pembangunan, 9(1), 1-27.

Purwaningsih, Y., Sutomo, \& Istiqomah, N. (2015). Analisis Dampak Alih Fungsi Lahan terhadap Tingkat Ketahanan Pangan Rumah Tangga Petani di Karanganyar ,. 1(2). https://doi.org/10.18196/agr.1213

Putri, Z. R. (2015). Analisis Penyebab Alih Fungsi Lahan Pertanian ke Lahan Non Pertanian Kabupaten/Kota di Provinsi Jawa Tengah 2003-2013. Eko-Regional, 10(1), 17-22.

Rahmawati, E. (2012). Aspek Distribusi pada Ketahanan Pangan Masyarakat di Kabupaten Tapin. Agribisnis Pedesaan, 02(3).

Santosa, S. P., \& Sudrajat. (2010). Kajian Ketersediaan dan Kebutuhan Konsumsi Beras di Kabupaten Karanganyar, Jawa Tengah. 1-11.

Suriadi, A. B. (2010). Perubahan Iklim dan Ketahanan Pangan di Jawa Barat. 12(1), 48-56.

Suryana, A. (2014). Menuju Ketahanan Pangan Indonesia Berkelanjutan 2025: Tantangan dan Penanganannya. Agro Ekonomi, 23(2), 123-135.

Susanti, I. (2017). Faktor-faktor yang Mempengaruhi Volume Beras Impor di Jawa Timur. Penelitian Ekonomi Dan Akutansi, II(1), 295-319.

Undang-undang Nomor 7, 1996. (1996). Tentang Pangan.

Wibowo, C. S. (2018). Dampak Pengalihan Fungsi Lahan Sawah Pada Produksi Padi Sampai Tahun 2018 dan Implikasinya Terhadap Ketahanan Pangan Wilayah ( Studi Di Kecamatan Jaten Kabupaten Karanganyar Propinsi Jawa Tengah ). Ketahanan Naional, 21, 107-117.

Windiani, R. (2012). "Bali Ndeso Mbangun Deso" dan Ketahanan Pangan Daerah Provinsi Jawa Tengah. Politika, 3(1), 1-25. 